\title{
Safety of Endobronchial Ultrasound-Guided Transbronchial Needle Aspiration for Patients Taking Clopidogrel: A Report of 12 Consecutive Cases
}

\author{
David R. Stather Paul MacEachern Alex Chee Alain Tremblay \\ Division of Respiratory Medicine, University of Calgary, Calgary, Alta., Canada
}

\section{Key Words}

Interventional bronchoscopy - Transbronchial needle aspiration $\cdot$ Endobronchial ultrasound $\cdot$ Clopidogrel

\begin{abstract}
Background: Clopidogrel is an oral agent commonly used for primary or secondary prevention of cardiovascular disease. It is associated with an increased risk of bleeding during some medical and surgical procedures. Endobronchial ultrasound-guided transbronchial needle aspiration (EBUSTBNA) is a new bronchoscopic technique used to accurately biopsy intrathoracic structures during flexible bronchoscopy. It is currently unknown whether clopidogrel increases bleeding complications during EBUS-TBNA procedures. Objectives: To evaluate the safety of clopidogrel use in EBUSTBNA by identifying consecutive cases of EBUS-TBNA procedures performed on patients taking clopidogrel. Methods: A retrospective review of a prospectively collected quality improvement database from 1,100 consecutive pulmonary procedures performed by an interventional pulmonologist (D.R.S.) at the University of Calgary from July 1st, 2007 to April 1st, 2011 was performed. Results: Twelve cases of EBUSTBNA procedures performed on patients taking clopidogrel
\end{abstract}

were identified. Mean age was 74 years (range 61-85). Seven patients $(66.7 \%)$ were taking aspirin in addition to clopidogrel. There was no significant bleeding seen in any cases at the time of bronchoscopy and no additional complications were identified during follow-up (at least 4 weeks; median follow-up 3 months). Conclusions: This series of 12 cases suggests that EBUS-TBNA can be performed safely by experienced operators in patients taking clopidogrel. Nevertheless, until larger prospective studies confirm this hypothesis, proceeding to EBUS-TBNA without first withdrawing clopidogrel should only be performed in situations where the risk of short-term thrombosis is believed to outweigh the (theoretical) risk of bleeding.

Copyright $\odot 2012$ S. Karger AG, Basel

\section{Introduction}

Clopidogrel is a commonly utilized oral medication, used to prevent thrombosis in patients with coronary artery stenting, acute coronary syndromes and cerebrovascular disease [1-6]. It is a thienopyridine compound that inhibits adenosine diphosphate-induced platelet aggregation [7].

\section{KARGER}

Fax +4161306 1234 E-Mail karger@karger.ch www.karger.com (c) 2012 S. Karger AG, Basel

0025-7931/12/0834-0330\$38.00/0

Accessible online at:

www.karger.com/res
David R. Stather, MD, FRCPC, FCCP

Division of Respiratory Medicine, Health Sciences Center

3330 Hospital Dr. NW

Calgary, AB T2N 4N1 (Canada)

Tel. +1 403210 3866, E-Mail davestather@yahoo.ca 
Patients presenting with an acute coronary syndrome without ST-segment elevation have higher major bleeding complication rates with clopidogrel than with aspirin alone [1]. The use of clopidogrel also increases the risk of hematoma at the time of pacemaker or implantable cardioverter-defibrillator implantation [8], and increases hemorrhagic complications in patients undergoing cardiac surgery [9]. Although the use of aspirin is not associated with an increased risk of bleeding during transbronchial lung biopsy [10], clopidogrel has been shown to significantly increase the risk of bleeding during bronchoscopy when transbronchial lung biopsies are performed [11].

Premature discontinuation of clopidogrel therapy after drug-eluting stent implantation is associated with an increased risk of stent thrombosis [12-16] and other cardiovascular events including death [12]. It is therefore recommended that clopidogrel be continued for some low-risk medical procedures, such as esophagogastroduodenoscopy and colonoscopy $[17,18]$. For higher-risk procedures (such as the endoscopic treatment of varices) it is recommended that the endoscopist liases with a cardiologist and stops the clopidogrel at least 7 days before the procedure [17].

Endobronchial ultrasound-guided transbronchial needle aspiration (EBUS-TBNA) is a new, minimally invasive pulmonary procedure used to diagnose pulmonary diseases by allowing visualization and safe, highly accurate biopsies of intrathoracic structures during bronchoscopy $[19,20]$. As the use of EBUS-TBNA continues to proliferate, new procedure-related complications are being reported [21-24]. It is unknown whether clopidogrel increases bleeding complications during endobronchial ultrasound procedures.

Initial success with several patients for whom it was felt that the risk of stopping the clopidogrel before EBUSTBNA outweighed the theoretical bleeding risk, led to a practice pattern of performing EBUS-TBNA in patients while they were on clopidogrel. We report 12 such patients, all of whom had no complications.

\section{Methods}

Cases were obtained by reviewing a prospectively collected quality improvement database from all consecutive pulmonary procedures performed by an interventional pulmonologist (D.R.S.) at the University of Calgary from July 1st, 2007 to April 1st, 2011. The majority of data points were entered into an SPSS file at the time of the procedure, including whether or not the patient was taking clopidogrel and any immediate complications (e.g. significant bleeding). Significant bleeding was defined as $>5$ $\mathrm{ml}$ and/or requiring interruption of the procedure and/or any specific intervention such as topical iced saline/epinephrine application. Procedure results and complications were entered at 6-8 weeks after the procedure. One additional case from a second interventional pulmonologist (P.M.) was included. No other cases of EBUS-TBNA in patients receiving clopidogrel were performed in our center in this time period.

EBUS-TBNA was performed on an outpatient basis under local anesthesia and conscious sedation without endotracheal intubation. Following airway examination, endobronchial ultrasonograpy was performed (BF-UC160F, Olympus Canada; Richmond Hill, Ont., Canada) followed by sampling of targeted lesions with a 22- or 21-gauge needle (NA-201SX-4022-C and 21-C; Olympus Canada) under direct ultrasound visualization. Rapid on-site evaluation of specimens was not performed.

Analysis of the database for research purposes was approved by the Calgary Health Research Ethics Board (Ethics ID: E-23801).

\section{Results}

From September 1st, 2009 to April 1st 2011, 12 cases were identified of EBUS-TBNA on patients who were taking clopidogrel (table 1). Mean age was 74 years (range 61-85) and 7 patients (66.7\%) were taking aspirin in addition to the clopidogrel. The first 6 cases were performed using a 22-gauge needle and the others with a 21-gauge needle.

A total of 24 lymph node stations and 2 lung masses were aspirated. A minimum of 2 and a maximum of 4 passes were made per lymph node station. A specific diagnosis was obtained in 8 of $12(66.7 \%)$ patients, with the remaining 4 demonstrating benign nodal tissue which was confirmed upon follow-up or additional testing. No appropriate additional bronchoscopic samples were obtained other than bronchoalveolar lavage. One patient required repeat bronchoscopy after the discontinuation of clopidogrel so that transbronchial biopsies could be performed (case 4, chronic eosinophilic pneumonia).

There was no significant bleeding seen in any of the cases at the time of bronchoscopy. The mean follow-up period was 12.7 months (median $=3$ months), with all patients followed up to at least 4 weeks after the procedure having no complications.

\section{Discussion}

To our knowledge, this series of 12 consecutive cases is the first report suggesting the safety of EBUS-TBNA in patients taking clopidogrel. We are also unaware of any reported cases of significant bleeding in this setting. 
Table 1. The 12 cases

\begin{tabular}{|c|c|c|c|c|c|c|c|c|}
\hline Case & Age & Sex & ASA & $\begin{array}{l}\text { Clopidogrel } \\
\text { indication }\end{array}$ & EBUS-TBNA indication & Samples/results & Diagnosis & Follow-up \\
\hline 1 & 78 & M & yes & $\mathrm{CAD} /$ stent & $\begin{array}{l}\text { lung cancer staging and } \\
\text { diagnosis }\end{array}$ & $\begin{array}{l}4 \mathrm{R}, 7=\text { normal LN, left lower- } \\
\text { lobe mass = adenocarcinoma }\end{array}$ & adenocarcinoma of the lung & 2.5 years \\
\hline 2 & 71 & M & yes & CAD/stent & $\begin{array}{l}\text { persistant mediastinal } \\
\text { adenopathy after } \\
\text { pneumonia }\end{array}$ & $\begin{array}{l}11 \mathrm{R}=\text { normal LN } \\
7=\text { anthracotic } \mathrm{LN}\end{array}$ & $\begin{array}{l}\text { reactive adenopathy (resolved } \\
\text { on repeat imaging) }\end{array}$ & 6 months \\
\hline 3 & 81 & $\mathrm{~F}$ & no & CVA & mediastinal adenopathy & 7 = NCG, $4 \mathrm{R}, 11 \mathrm{R}=$ normal LN & sarcoidosis & 12 months \\
\hline 4 & 78 & $\mathrm{~F}$ & yes & $\mathrm{CAD} /$ stent & $\begin{array}{l}\text { mediastinal adenopathy/ } \\
\text { interstitial lung disease }\end{array}$ & $\begin{array}{l}7,4 \mathrm{~L}, 4 \mathrm{R}=\text { normal } \mathrm{LN}, \mathrm{BAL}= \\
30 \% \text { eosinophils } \\
\text { repeat bronchoscopy, off } \\
\text { clopidogrel, revealed CEP in } \\
\text { transbronchial biopsy }\end{array}$ & $\begin{array}{l}\text { chronic eosinophilic } \\
\text { pneumonia }\end{array}$ & 4 years \\
\hline 5 & 74 & $\mathrm{M}$ & no & $\mathrm{CAD} / \mathrm{CVA}$ & $\begin{array}{l}\text { right lower-lobe mass and } \\
\text { mediastinal adenopathy }\end{array}$ & $11 \mathrm{R}, 7=$ adenocarcinoma & adenocarcinoma of the lung & 3 months \\
\hline 6 & 72 & $\mathrm{~F}$ & yes & $\mathrm{CAD} /$ stent & $\begin{array}{l}\text { lung masses and } \\
\text { mediastinal adenopathy }\end{array}$ & $12 \mathrm{R}, 7,11 \mathrm{~L}=$ adenocarcinoma & adenocarcinoma of the lung & 2 months \\
\hline 7 & 71 & M & yes & $\mathrm{CAD} /$ stent & $\begin{array}{l}\text { right upper-lobe mass and } \\
\text { mediastinal adenopathy }\end{array}$ & $4 \mathrm{R}=$ adenocarcinoma & adenocarcinoma of the lung & 3 months \\
\hline 8 & 61 & $\mathrm{~F}$ & no & CVA & $\begin{array}{l}\text { bronchiectasis and large } \\
11 \mathrm{R}\end{array}$ & $11 \mathrm{R}=$ normal $\mathrm{LN}$ & mycobacterium avium complex & 3 years \\
\hline 9 & 67 & $\mathrm{~F}$ & yes & $\mathrm{CAD} /$ stent & $\begin{array}{l}\text { prior non-small-cell lung } \\
\text { cancer (resected) now with } \\
\text { large } 4 \mathrm{R}\end{array}$ & $4 \mathrm{R}=$ squamous cell carcinoma & $\begin{array}{l}\text { squamous cell carcinoma of the } \\
\text { lung }\end{array}$ & 3 months \\
\hline 10 & 81 & $\mathrm{~F}$ & no & CVA & $\begin{array}{l}\text { smoker with mediastinal } \\
\text { adenopathy and lung mass }\end{array}$ & $\begin{array}{l}7, \text { left lower-lobe mass = } \\
\text { small-cell carcinoma }\end{array}$ & small-cell lung cancer & 1 month \\
\hline 11 & 85 & $\mathrm{M}$ & yes & CVA/CAD & $\begin{array}{l}\text { smoker with UIP and } \\
\text { borderline adenopathy and } \\
\text { left upper-lobe nodule }\end{array}$ & $11 \mathrm{R}, 4 \mathrm{R}, 11 \mathrm{~L}=$ normal LN & $\begin{array}{l}\text { staging bronchoscopy = stage } \\
\text { IA non-small-cell lung cancer }\end{array}$ & 3 months \\
\hline 12 & 73 & $\mathrm{M}$ & yes & CVA/CAD & $\begin{array}{l}\text { smoker with right hilar } \\
\text { mass }\end{array}$ & $11 \mathrm{R}, 12 \mathrm{R}=$ small-cell lung cancer & limited small-cell lung cancer & 5 months \\
\hline
\end{tabular}

In all cases, no significant bleeding was seen at bronchoscopy, no procedure-related complications occurred and clopidogrel dose $=75 \mathrm{mg}$ once daily orally.

$\mathrm{ASA}=$ Aspirin $\mathrm{CAD}=$ coronary artery disease $\mathrm{CEP}=$ chronic eosinophilic pneumonia $\mathrm{CVA}=$ cerebrovascular disease $\mathrm{LN}=$ lymph node; $\mathrm{NCG}=$ noncaseating granuloma; UIP = usual interstitial pneumonitis.

This finding is important as it has been previously demonstrated that clopidogrel increases bleeding when performing other bronchoscopic procedures such as transbronchial biopsies [11]. Perhaps it is not surprising that bleeding may be more problematic in a technique that by design traumatizes pulmonary and peribronchial blood vessels. During EBUS-TBNA, on the other hand, aspirates are done with a small (22- or 21-gauge) needle with direct ultrasound visualization of the structures being biopsied, making major vascular puncture unlikely. EBUS-TBNA also affords the option of using Doppler to look for blood vessels if there is concern regarding indeterminate structures seen on the ultrasound image.

It should be noted that these results may not be generally applied to standard (i.e. not EBUS-guided) TBNA, as vascular puncture may be more likely. Even without anticoagulation or antiplatelet agents, a randomized study noted no bleeding complications in the EBUS-TBNA group, but moderate bleeding occurred in $7.7 \%$ of standard TBNA cases [20]. Such differences may only be exacerbated in the presence of clopidogrel.

While our practice had consistently been to discontinue clopidogrel prior to EBUS-TBNA, cases are now performed without discontinuation in patients deemed at high risk of thrombotic events after careful consideration of the risk/benefit of each approach. EBUS-TBNA has been associated with extremely low rates of bleeding [25]. In fact, a case has even been reported of an uncomplicated/successful EBUS-TBNA sampling of a hilar lung mass obtained by traversing the pulmonary artery [26]. On the other hand, the risks associated with the discon- 
tinuation of clopidogrel even for short periods of time can be significant in patients with recently placed bare $(<6$ weeks) or drug-eluting ( $<12$ months) coronary stents, or in patients with a history of recurrent cerebrovascular events. Unfortunately, no effective bridging regimen exists for these indications, unlike the common practice in patients on oral anticoagulation for atrial fibrillation or mechanical heart valves.

Due to the significant limitations and small size of this case series, we cannot definitively conclude that EBUSTBNA is safe in patients taking clopidogrel. The bronchoscopist was aware that the patient was taking clopidogrel at the time of bronchoscopy, and it is therefore possible that the attending physicians and the trainees involved in the procedures may have been more careful than usual with the positioning and manipulation of the needle. The operators involved also had extensive training and experience with this technique, which may have reduced the chance of complications to a greater degree than for a novice EBUS bronchoscopist. While the mean follow-up period was 12.7 months (median $=3$ months), with no significant complication in any patients (all of whom had a follow-up of at least 4 weeks after the procedure), it is possible that subclinical mediastinal or intralymph node bleeding may have occurred in a delayed fashion.

In summary, we present 12 consecutive cases where EBUS-TBNA was performed in patients taking clopidogrel, all of which had no complications. This suggests that EBUS-TBNA can be performed safely by experienced operators in patients on clopidogrel. However, further research and experience in larger groups of patients will be needed to confirm this hypothesis. Until such time, proceeding to EBUS-TBNA without first withdrawing clopidogrel should only be performed in situations where the risk of short-term thrombosis is believed to outweigh the (theoretical) risk of bleeding.

\section{Acknowledgments}

The University of Calgary received grants from Olympus Canada for support of an Interventional Pulmonary Medicine Training Program and for CME events relating to EBUS.

\section{References}

1 Yusuf S, Zhao F, Mehta SR, Chrolavicius S, Tognoni G, Fox KA: Effects of clopidogrel in addition to aspirin in patients with acute coronary syndromes without ST-segment elevation. N Engl J Med 2001;345:494-502.

-2 Yusuf S, Mehta SR, Zhao F, Gersh BJ, Commerford PJ, Blumenthal M, Budaj A, Wittlinger T, Fox KA: Early and late effects of clopidogrel in patients with acute coronary syndromes. Circulation 2003;107:966-972.

-3 Budai A, Yusuf S Mehta SR, Fox KA, Tognoni G, Zhao F, Chrolavicius S, Hunt D, Keltai M, Franzosi MG: Benefit of clopidogrel in patients with acute coronary syndromes without ST-segment elevation in various risk groups. Circulation 2002;106:16221626.

- 4 CAPRIE Steering Committee: A randomized, blinded trial of clopidogrel versus aspirin in patients at risk of ischemic events (CAPRIE). Lancet 1996;348:1329-1339.

$\checkmark 5$ Taniuchi M, Kurz HI, Lasala JM: Randomized comparison of ticlopidine and clopidogrel after intracoronary stent implantation in a broad patient population. Circulation 2001;104:539-543.

-6 Moussa I, Oetgen M Roubin G, Colombo A, Wang X, Iyer S, Maida R, Collins M, Kreps E, Moses JW: Effectiveness of clopidogrel and aspirin versus ticlopidine and aspirin in preventing stent thrombosis after corona- ry stent implantation. Circulation 1999;99: 2364-2366.

7 Verstraete M, Zoldhelyi P: Novel antithrombotic drugs in development. Drugs 1995;49: 856-884.

8 Kutinsky IB, Jarandilla R, Jewett M, Haines DE: Risk of hematoma complications after device implant in the clopidogrel era. Circ Arrhythm Electrophysiol 2010;3:312-318.

9 Herman CR, Buth KJ, Kent BA, Kirsch GM: Clopidogrel increases blood transfusion and hemorrhagic complications in patients undergoing cardiac surgery. Ann Thorac Surg 2010;89:397-402.

10 Herth FJ, Becker HD, Ernst A: Aspirin does not increase bleeding complications after transbronchial biopsy. Chest 2002;122:14611464.

-11 Ernst A, Eberhardt R, Wahidi M, Becker HD, Herth FJ: Effect of routine clopidogrel use on bleeding complications after transbronchial biopsy in humans. Chest 2006;129:734-737.

12 Rossini R, Capodanno D, Lettieri C, Musumeci G, Nijaradze T, Romanmo M, Lortkipanidze N, Cicorella N, Biondi Zoccai G, Sirbu V, Izzo A, Guagliumi G, Valsecchi O, Gavaszzi A, Angiolillo DJ: Prevalence, predictors, and long-term prognosis of premature discontinuation of oral antiplatelet therapy after drug-eluting stent implantation. Am J Cardiol 2011;107:186-194.
13 Jeremias A, Sylvia B, Bridges J, Kirtane AJ, Bigelow B, Pinto DS, Ho KK, Cohen DJ, Garcia LA, Cutlip DE, Carrozza JP Jr: Stent thrombosis after successful sirolimus-eluting stent implantation. Circulation 2004; 109:1930-1932.

14 Lakovou I, Schmidt T, Bonizzoni E, Ge L, Sangiorgi GM, Stankovic G, Airoldi F, Chieffo A, Montorfano M, Carlino M, Michev I, Corvaja N, Briguori C, Gerckens U, Grube E, Colombo A: Incidence, predictors, and outcome of thrombosis after successful implantation of drug-eluting stents. JAMA 2005;293:2126-2130.

15 Kuchulakanti PK, Chu WW, Torguson R, Ohlmann P, Rha SW, Clavijo LC, Kim SW, Bui A, Gevorkian N, Xue Z, Smith K, Fournadjieva J, Suddath WO, Satler LF, Pichard $\mathrm{AD}$, Kent KM, Waksman R: Correlates and long-term outcomes of angiographically proven stent thrombosis with sirolimus- and paclitaxel-eluting stents. Circulation 2006; 113:1108-1113.

16 Spertus JA, Kettelkamp R, Vance C, Decker C, Jones PG, Rumsfeld JS, Messenger JC, Khanal S, Peterson ED, Bach RG, Krumholz HM, Cohen DJ: Prevalence, predictors, and outcomes of premature discontinuation of thienopyridine therapy after drug-eluting stent placement: results from the PREMIER registry. Circulation 2006;113:2803-2809. 
-17 Veitch AM, Baglin TP, Gershlick AH, Harnden SM, Tighe R, Carins S: Guidelines for the management of anticoagulant and antiplatelet therapy in patients undergoing endoscopic procedures. Gut 2008;57:1322-1329.

- 18 Eisen GM, Baron TH, Dominitz JA, Faigel DO, Goldstein JL, Fohanson JHF, Mallery JS Raddawi HM, Vargo JJ, Waring JP, Fanelli RD, Wheeler-Harbough J: Guideline on the management of anticoagulation therapy for endoscopic procedures. Gastrointest Endosc 2002;55:775-779.

19 Herth FJ, Eberhardt R, Vilmann P, Krasnik M, Ernst A: Real-time endobronchial ultrasound guided transbronchial needle aspiration for sampling mediastinal lymph nodes. Thorax 2006;61:795-798.
20 Tremblay A, Stather DR, MacEachern P, Khalil M, Field SK: A randomized controlled trial of standard versus endobronchial utrasonography-guided transbronchial needle aspiration in patients with suspected sarcoidosis. Chest 2009;136:340-346.

21 Huang CT, Chen CY, Ho CC, Yu CJ: A rare constellation of empyema, lung abscess, and mediastinal abscess as a complication of endobronchial ultrasound-guided transbronchial needle aspiration. Eur J Cardiothorac Surg 2011;40:264-265.

22 Moffatt-Bruce SD, Ross P Jr: Mediastinal abscess after endobronchial ultrasound with transbronchial needle aspiration: a case report. J Cardiothorac Surg 2010;5:33.

$>23$ Gupta R, Park HY, Kim H, Um SW: Endobronchial inflammatory polyp as a rare complication of endobronchial ultrasoundtransbronchial needle aspiration. Interact Cardiovasc Thorac Surg. 2010;11:340-341.
24 Seinfort DP, Johnson DF, Irving LB: Infective complications from endobronchial ultrasound-transbronchial needle aspiration. Eur Resp J 2009;34:524-525.

25 Varela-Lema L, Fernandez-Villar A, RuanoRavina A: Effectiveness and safety of endobronchial ultrasound-transbronchial needle aspiration: a systematic review. Eur Respir J 2009;33:1156-1164.

26 Vincent B, Huggins JT, Doelken P, Silvestri G: Successful real-time endobronchial ultrasound-guided transbronchial needle aspiration of a hilar lung mass obtained by traversing the pulmonary artery. J Thorac Oncol 2006;1:362-364. 